\title{
EVALUATION OF RAFTLIN MRNA IN HEPATOCELLULAR CARCINOMA
}

\author{
Mariam Sameh Boshra', Mahmoud Shawky El Meteini ${ }^{2}$, Ayman El-Sayed Shafei ${ }^{3}$, \\ Marwa Matboly ${ }^{1}$ and Hebatalla Said Ali ${ }^{1}$
}

${ }^{1}$ Medical Biochemistry and Molecular biology department, ${ }^{2}$ Surgery department, Faculty of Medicine, Ain Shams University, ${ }^{3}$ Biomedical Research Department, Armed Forces College of Medicine, Cairo, Egypt.

Corresponding author: Mariam Sameh Boshr

Mobile: 01223756578.

E mail:

mariamsameh09@gmail.com

Received: $18 / 4 / 2019$

Accepted: 15/5/2019

\begin{abstract}
:
Background: Hepatocellular carcinoma (HCC) is the most common primary hepatic malignancy of adults. It is the sixth most common cancer worldwide and the second most common cause of cancer death. More than $60 \%$ of patients are diagnosed with latestage disease after metastasis has occurred, resulting in an overall 5year survival rate of $<16 \%$.
\end{abstract}

Aim of the work: To characterize new diagnostic marker for HCC that can help in early diagnosis.

Patients and methods: 103 subjects were included in this study stratified into 3 groups, healthy controls, patients with HCC and patients with HCV. Serum and tissue samples were obtained. Bioinformatics analysis to retrieve $m R N A$ relevant to HCC, real time PCR for determining the relative expression of RAFTLIN mRNA in sera and tissue samples.

Results: There was statistically significant difference in the expression of RAFTLIN mRNA among patients with HCC compared with the other two groups.

Conclusion: The results demonstrated the promising role of RAFTLIN mRNA as a novel marker for early detection of HCC.

Key words: HCC, Hepatocellular carcinoma, mRNA.

\section{INTRODUCTION:}

Hepatocellular Carcinoma (HCC) is one of the most common malignant tumors in the world. It is a heterogeneous group of a tumor that vary in risk factor, genetic and epigenetic alteration event ${ }^{(\mathbf{1})}$. In Egypt, HCC is the fourth most common cancer and is the second cause of cancer mortality in both sexes ${ }^{(2)}$. Hepatocellular carcinoma occurs in a number of preexisting conditions that commonly includes hepatitis $\mathrm{C}$ and $\mathrm{B}$, alcoholic and nonalcoholic cirrhosis ${ }^{(3)}$.

Contributing to the poor prognosis of HCC is the lack of specific symptoms in the early stages of the disease. More than $60 \%$ of patients are diagnosed with late-stage disease after metastasis has occurred, resulting in an overall 5-year survival rate of $<16 \%{ }^{(4)}$. In contrast, patients diagnosed with early stage disease have a relatively good prognosis, with a 5-year survival rate of $>$ $70 \%$ (5).

Current gold standard and most commonly used biomarker for patients at risk for $\mathrm{HCC}$ is alpha-fetoprotein (AFP) along with ultrasound every 6 to 12 months which is far from perfect. Unfortunately, AFP serum concentrations do not correlate well with the prognostic values of HCC such as tumor size, stage, or disease progression, and ethnic variability may also exist. Furthermore, in some cases of HCC, AFP elevations are not apparent at all. Ultrasound surveillance even performed every three months cannot improve detection of small 
HCC nodules because of limitations in recall procedures $^{(\mathbf{6})}$.

A better understanding of molecular mechanisms involved in tumorigenesis and metastasis of HCC will provide novel diagnostic and potential therapeutic implications in HCC treatment.

Due to previous findings, we were challenged to study an RNA-based biomarker specific to $\mathrm{HCC}$ for its promising role in diagnosis and prognosis of $\mathrm{HCC}$.

Initially, we used in silico data analysis to identify an $\mathrm{HCC}$ associated gene (RAFTLIN).Then, we assessed its expression levels in the sera and tissue of patients with $\mathrm{HCC}$, compared with those in chronic hepatitis $\mathrm{C}$ virus (CHC)-infected patients and healthy controls.

\section{MATERIAL AND METHODS:}

The current study included 49 patients with HCC. The American Association for the Study of Liver Diseases (AASLD) practice guidelines were applied for diagnosis. Barcelona Clinic Liver Cancer classification was used for classification of patients into $45(91.8 \%)$ early stages and 4 $(8.2 \%)$ late stages carcinoma patients. The complete follow-up data for each patient was collected. Blood samples from the patients were collected before any therapeutic interventions. Hepatocellular carcinoma and corresponding non-tumor fresh specimens were obtained from 20 out of the 49 HCC patients who underwent surgical tumor resection. We excluded any patient that received radiotherapy or chemotherapy.
Moreover, 18 CHC-infected patients' serum samples were collected from internal medicine department, Ain Shams University Hospital. 36 healthy control serum samples were also collected during routine check-ups from July 2017 to March 2018. Both CHC-infected patients and the healthy persons were considered as the control group of the study; they matched the HCC group in age and sex.

All blood samples were centrifuged to collect sera and then kept at $-80^{\circ} \mathrm{C}$ until further steps. The liver tissue specimens were collected and stored at $-80 \quad \mathrm{C}$ immediately after resection for the extraction of RNA. Written informed consents were obtained from all the participants in accordance with the Declaration of Helsinki. The Ethics Committee of the Ain Shams Faculty of Medicine, Egypt approved this study.

\section{- $\quad$ viral markers and AFP:}

HCV antibody and AFP level were obtained from patients' data sheets.

- Bioinformatics-based selection of the RNA-based biomarker:

Raftlin, Lipid Raft Linker 1 (RAFTLIN) was chosen according to public microarray databases, because this gene plays a major role in HCC. To confirm the expression of RAFTLIN gene (RAFTLIN mRNA) in HCC cases; we searched Gene Atlas database (available at https://www.ebi.ac. uk/gxa/home) figure (1) and we verified the expression of RAFTLIN in the liver using genecards database available https://www. genecards. org/ as shown in figure (2). 


\section{Evaluation of raftlin mrna in hepatocellular carcinoma}

Figure 1: print screen shows the expression of RAFTLIN mRNA in liver from gene atlas database.

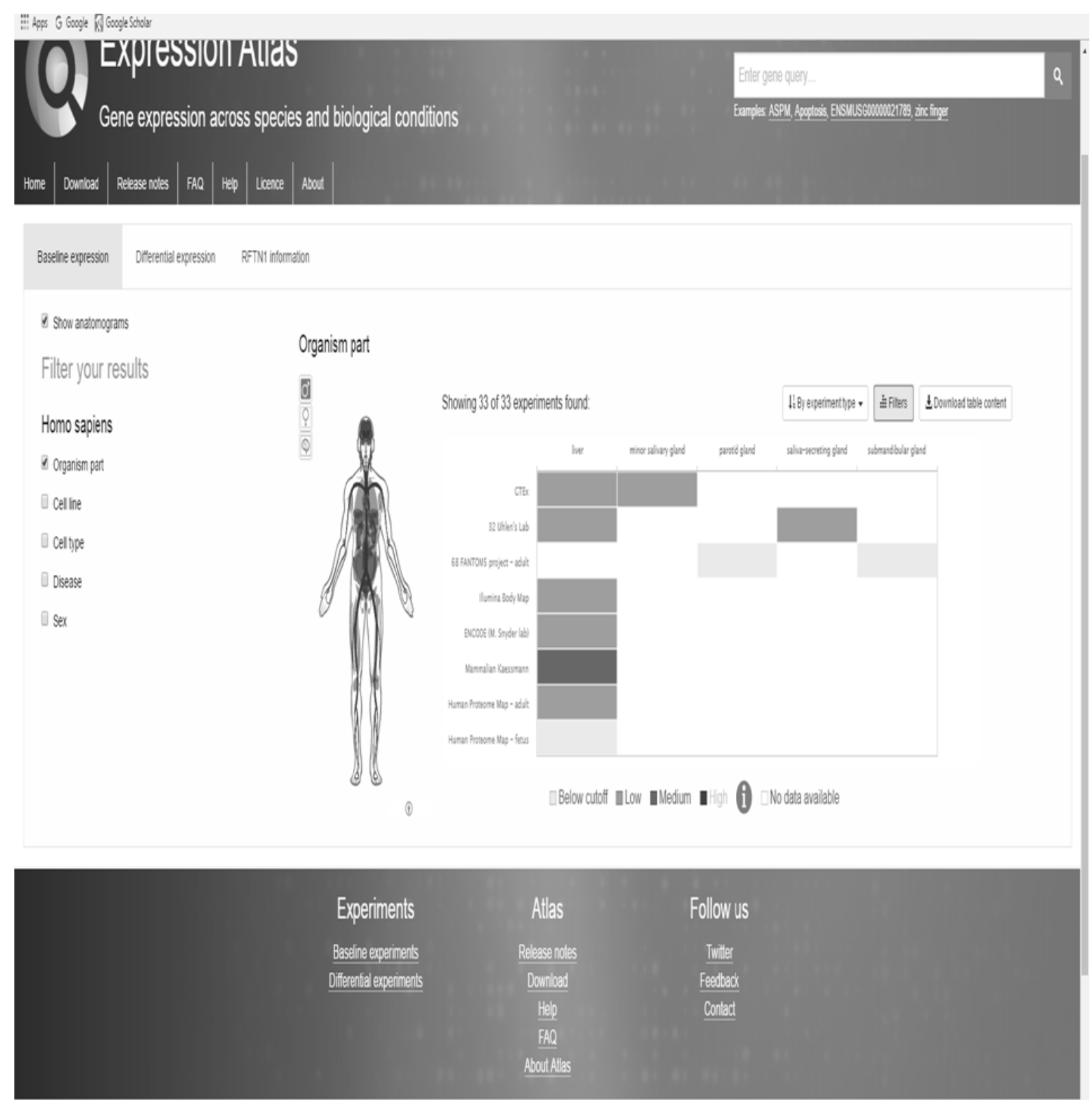


Figure 2: Snapshot shows the verification of expression of RAFTLIN gene in normal liver tissue available at https://www.genecards.org/.

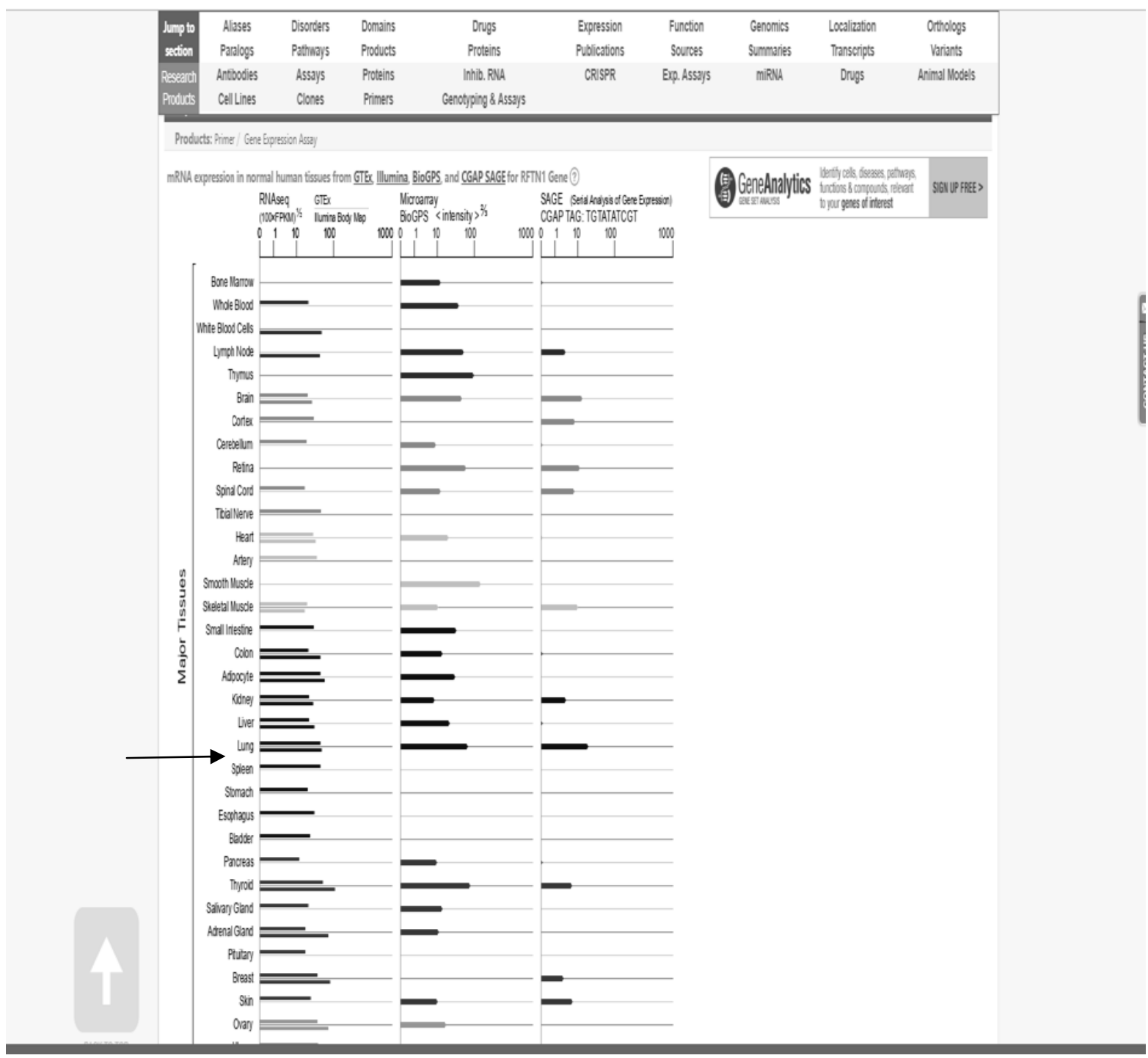

validation of the chosen RNA based biomarker in human clinical samples by q PCR:

1. Extraction of total RNA from human serum and tissue samples.

We used miRNeasy extraction kit (Qiagen, USA; Cat no. 217004) to extract total RNA from the serum samples following the manufacturer's instructions. We assessed the RNA concentration and integrity using an Ultraspec $1000 \mathrm{UV} /$ visible spectrophotometer (Amersham Pharmacia Biotech, Cambridge, England). Seventy-two $\mu \mathrm{L}$ of DEPC-water was added to $3 \mu \mathrm{L}$ of RNA solution (dilution 1:25). The samples were read at $260 \mathrm{~nm}$ for RNA detection and $280 \mathrm{~nm}$ for protein detection using a spectrophotometer. $40 \quad \mu \mathrm{g} \quad \mathrm{RNA} / \mathrm{mL}$ is equivalent to 1 absorbance, so the concentration of RNA in a sample $(\mu \mathrm{g} / \mathrm{mL})=$ sample absorbance at $260 \mathrm{~nm} \times 40 / 1 \times$ dilution factor $^{(7)}$. The samples were considered to have high RNA quality if RNA: protein ratio (260:280 ratio) was above 1.8-2. Then the extracted total RNA underwent reversed transcription into cDNA using a miScript II RT Kit (Qiagen) as per the manufacturer's 
protocol using a Hybaid thermal cycler (Thermo Electron, Waltham, MA).

2. Quantitative real time-PCR of the RNA-based biomarker panel:

The level of RAFTLIN mRNA in sera was measured using a Quantitect SYBR Green Master Mix Kit (Qiagen), using the Applied biosystem 7500 real-time PCR system (Foster city, USA) and specific primers (Accession: NM_015150) supplied by Qiagen. GADPH (Accession NM 001101) was used as a housekeeping gene.

Each reaction was performed in duplicate. The Applied biosystem 7500 manual was used to calculate the threshold cycle (CT) value of each sample. CT values more than 36 were considered negative. The specificities of the amplicons for the SYBR Green-based PCR amplification were affirmed by the melting curves. The $2^{-\Delta \Delta \mathrm{Ct}}$ technique was used to measure the expression of the RNA-based biomarker panel ${ }^{(\mathbf{8})}$. Housekeeping gene was used as an invariant control to normalize the raw data of the samples and compare these results with a reference sample. $\underline{\text { Statistics: }}$

Statistical Package for the Social Sciences (SPSS, Chicago, IL) version 20 was used to perform all statistical analyses. Chi-square tests, Kruskal-Wallis and oneway analysis of variance were used for comparison as appropriate. Receiver operating characteristic (ROC) curve was used to explore the predictive value of the chosen RNA-based biomarker for HCC. The relationships between the RNA-based biomarker panel expression levels and the clinic-pathological parameters were assessed using Spearman rank correlations. A 2-tailed $P$ value of .05 or less was considered to indicate a statistically significant difference.

\section{RESULTS:}

\section{Description of the study population:}

No statistical significant differences were found regarding age, sex or smoking among the three groups ( $>>0.05)$. Details of the demographic and clinical data are shown in Table (1).

Table 1: The Clinicopathological Factors in Different Groups Of the study.

\begin{tabular}{|c|c|c|c|c|c|}
\hline & $\begin{array}{c}\text { Malignant } \\
\text { (HCC) } \\
\text { N (\%) } \\
\end{array}$ & $\begin{array}{c}\text { CHC } \\
(\mathrm{HCV}) \\
\mathbf{N}(\%) \\
\end{array}$ & $\begin{array}{l}\text { Healthy } \\
\text { Control } \\
\text { N }(\%) \\
\end{array}$ & $\chi^{2(a)}$ & $\mathbf{P}$ \\
\hline $\begin{array}{l}\text { Mean age: } \\
\geq \mathbf{5 6 . 5} \text { years } \\
<\mathbf{5 6 . 5} \text { years } \\
\end{array}$ & $\begin{array}{l}30(61.2 \%) \\
19(38.8 \%)\end{array}$ & $\begin{array}{c}11(61.1 \%) \\
7(38.9 \%)\end{array}$ & $\begin{array}{l}15(41.7 \%) \\
21(58.3 \%)\end{array}$ & $\chi^{2(a)}=3.599$ & $0.165 \mathrm{NS}$ \\
\hline $\begin{array}{l}\text { Sex: } \\
\text { Male (61) } \\
\text { Female (42) }\end{array}$ & $\begin{array}{l}30(61.2 \%) \\
19(38.8 \%)\end{array}$ & $\begin{array}{c}10(55.6 \%) \\
8(44.4 \%)\end{array}$ & $\begin{array}{l}21(58.3 \%) \\
15(41.7 \%) \\
\end{array}$ & $\chi^{2(a)}=0.193$ & $.908 \mathrm{NS}$ \\
\hline $\begin{array}{l}\text { Smoking: } \\
\text { Smoker (47) } \\
\text { Non-Smoker (56) }\end{array}$ & $\begin{array}{l}22(44.9 \%) \\
27(55.1 \%)\end{array}$ & $\begin{array}{c}7(38.9 \%) \\
11(61.1 \%)\end{array}$ & $\begin{array}{l}18(50 \%) \\
18(50 \%)\end{array}$ & $\chi^{2(a)}=0.617$ & $.734 \mathrm{NS}$ \\
\hline $\begin{array}{l}\text { HCV-antibodies: } \\
\text { Positive (64) } \\
\text { Negative (39) }\end{array}$ & $\begin{array}{c}46(93.9 \%) \\
3(6.1 \%) \\
\end{array}$ & $\begin{array}{c}18(100 \%) \\
0(0 \%) \\
\end{array}$ & $\begin{array}{c}0(0 \%) \\
36(100 \%) \\
\end{array}$ & $\chi^{2(a)}=91.029$ & $.000 * *$ \\
\hline $\begin{array}{l}\text { Cirrhosis: } \\
\text { Cirrhotic(60) } \\
\text { Non-cirrhotic(43) }\end{array}$ & $\begin{array}{c}45(91.8 \%) \\
4(8.2 \%)\end{array}$ & $\begin{array}{c}15(83.3 \%) \\
3(16.7 \%)\end{array}$ & $\begin{array}{c}0(0 \%) \\
36(100 \%)\end{array}$ & $\chi^{2(a)}=77.615$ & $.000 * *$ \\
\hline $\operatorname{AST}(\mathrm{IU} / \mathrm{L})$ & $64.07 \pm 50.2$ & $62.2 \pm 36.46$ & $17.30 \pm 1.81$ & $\mathrm{~F}^{(\mathrm{b})}=51.58$ & $.000 * *$ \\
\hline $\operatorname{ALT}(\mathrm{IU} / \mathrm{L})$ & $48.4 \pm 39.5$ & $39.6 \pm 20.11$ & $14.8 \pm 5.2$ & $\mathrm{~F}^{(\mathrm{b})}=45.37$ & $.000 * *$ \\
\hline
\end{tabular}


Mariam Sameh Boshra, et al.,

\begin{tabular}{|c|c|c|c|c|c|}
\hline Albumin (g/dl) & $3.39 \pm 0.74$ & $2.66 \pm 0.75$ & $4.66 \pm 0.40$ & $\mathrm{~F}^{(\mathrm{b})}=53.85$ & $.000 * *$ \\
\hline Total & $1.929 \pm 1.212$ & $1.28 \pm 0.40$ & $0.43 \pm 0.09$ & $\mathrm{~F}^{(\mathrm{b})}=62.71$ & $.000 * *$ \\
\hline Direct & $1.04 \pm 0.84$ & $0.67 \pm 0.27$ & $0.19 \pm 0.07$ & $\mathrm{~F}^{(\mathrm{b})}=57.88$ & $.000 * *$ \\
\hline INR & $1.37 \pm 0.21$ & $1.15 \pm 0.18$ & $0.88 \pm 0.14$ & $\mathrm{~F}^{(\mathrm{b})}=57.49$ & $.000 * *$ \\
\hline AFP (ng/ml) & $155.6 \pm 485.7$ & $23.3 \pm 9.8$ & $2.6 \pm 0.8$ & $\mathrm{~F}^{(\mathrm{b})}=62$ & $.000 * *$ \\
\hline \multicolumn{2}{|l|}{ Child Pugh score } & & & & \\
\hline A4 & $1(2 \%)$ & & & & \\
\hline A5 & $18(36.7 \%)$ & & & & \\
\hline A6 & $8(16.3 \%)$ & & & & \\
\hline B5 & $2(4.1 \%)$ & & & & \\
\hline B6 & $1(2 \%)$ & & & & \\
\hline B7 & $6(12.2 \%)$ & & & & \\
\hline B8 & $9(18.4 \%)$ & & & & \\
\hline $\mathrm{C} 10$ & $4(8.2 \%)$ & & & & \\
\hline \multicolumn{2}{|l|}{$\begin{array}{l}\text { Average size of the } \\
\text { tumor }\end{array}$} & & & & \\
\hline$<3 \mathrm{~cm}$ & $12(24.5 \%)$ & & & & \\
\hline$\geq 3 \mathrm{~cm}$ & $37(75.5 \%)$ & & & & \\
\hline \multicolumn{2}{|l|}{ BCLC stage } & & & & \\
\hline Early & $45(91.8 \%)$ & & & & \\
\hline Late & $4(8.2 \%)$ & & & & \\
\hline
\end{tabular}

a Chi- square test, $\mathrm{b}$ : kruskal-wallis test. $\mathrm{p}$ : NS; not significant $(>0.05),{ }^{*} \mathrm{p}<0.05$ :is significant, ${ }^{* *} \mathrm{p}<$ 0.01: is highly significant. AFP : serum Alpha Fetoprotein, CHC: Chronic hepatitis C (HCV positive), AST: Aspartate Transaminase, ALT: Alanine Transaminase, INR: International Normalized Ratio, $\mathrm{n}=103$.

\section{Expression of the serum RAFTLIN mRNA among the study groups:}

The Mean Rank relative quantity (RQ) values of RAFTLIN in the malignant group, the Chronic HCV group and healthy control, were $69.79,37.83$, and 34.88 respectively. Thus, the malignant group showed significant higher expression levels of RAFTLIN $m R N A(\mathrm{p}<0.001)$ in their sera than non-malignant groups, as revealed in Figure (3) and Table (2).

Table 2: Expression of serum RAFTLIN mRNA among the study groups.

\begin{tabular}{|c|c|c|c|c|c|c|c|c|}
\hline & \multicolumn{6}{|c|}{ Group } & \multirow{3}{*}{$\chi^{2(a)}$} & \multirow{3}{*}{$\mathrm{p}$} \\
\hline & \multicolumn{2}{|l|}{$\mathrm{HCC}$} & \multicolumn{2}{|l|}{$\mathrm{HCV}$} & \multicolumn{2}{|c|}{ Healthy Control } & & \\
\hline & Median & $\begin{array}{l}\text { Mean } \\
\text { rank }\end{array}$ & Median & $\begin{array}{l}\text { Mean } \\
\text { rank }\end{array}$ & Median & $\begin{array}{l}\text { Mean } \\
\text { rank }\end{array}$ & & \\
\hline $\begin{array}{l}\text { RQ of } \\
R A F T L I N \\
\text { mRNA }\end{array}$ & 8 & 69.79 & 0.81 & 37.83 & 1 & 34.88 & 15.86 & $.000 * *$ \\
\hline
\end{tabular}

a: Kruskal Wallis test, HCC: Hepatocellular carcinoma, HCV: Hepatitis C virus, mRNA: messenger ribonucleic acid, RQ: Relative quantification, ${ }^{* *} \mathrm{p}<0.01$ : Highly Significant difference. 
Figure 3: BOXPLOT of Serum RAFTLIN determined by qRT-PCR among the HCC, CHC, and healthy control groups. The data present the median fold changes $\mathrm{n}=103$.

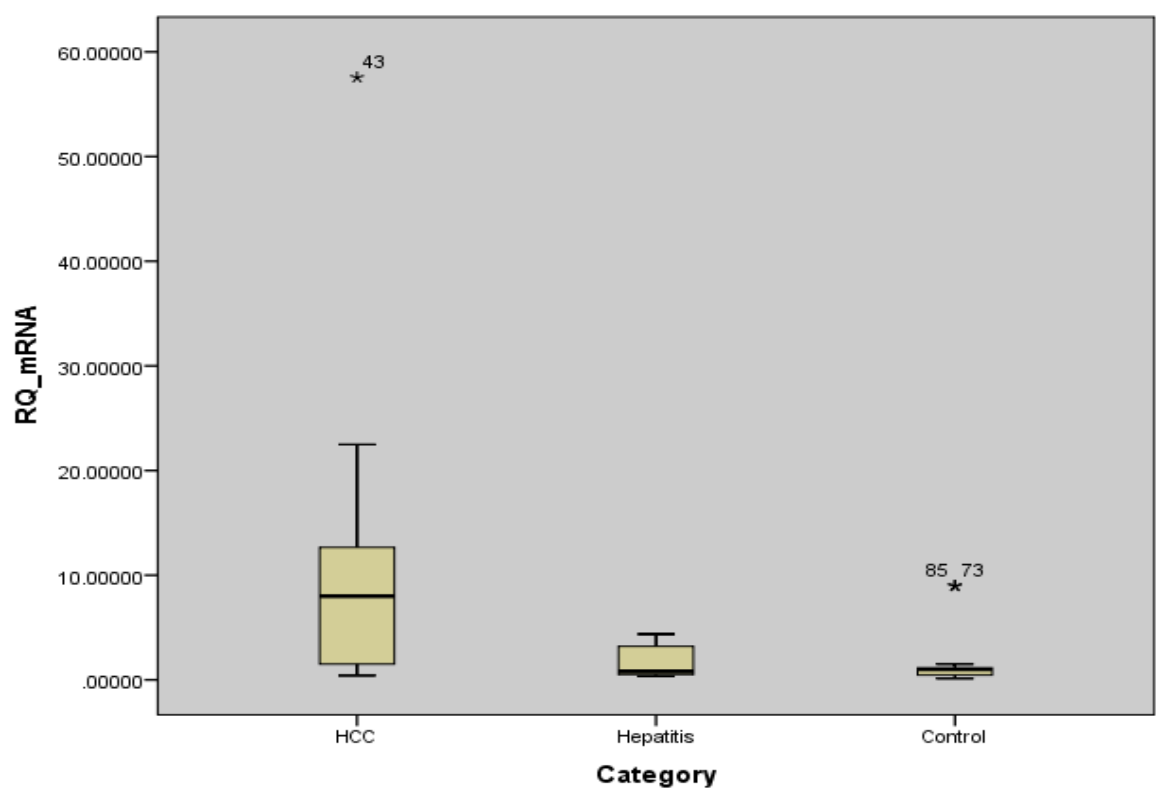

The best discriminating cut-off values according to the ROC curve when comparing the HCC patients with control, for RAFTLIN mRNA was 1.52, respectively as shown in Figure (4).

Figure 4: ROC for prediction of HCC using fold change of RAFTLIN.

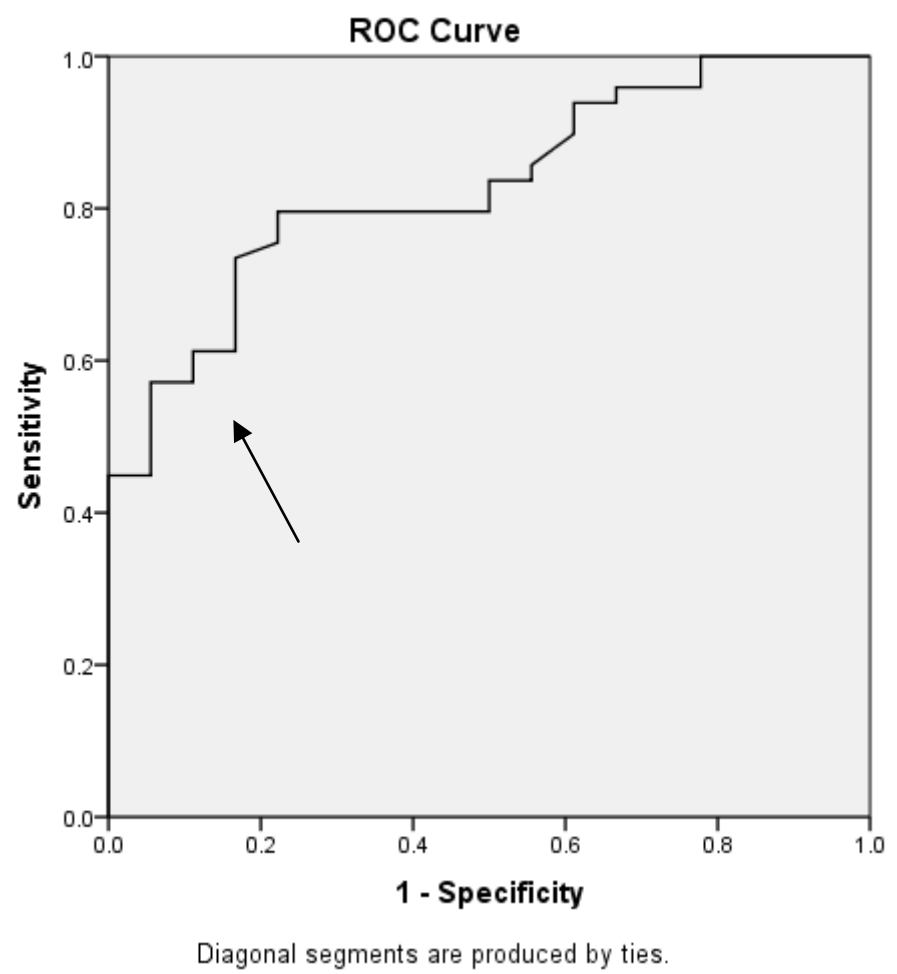

The positivity rates of RAFTLIN $m R N A$ was $73.5 \%$ in the malignant group. While among the CHC patients, the positivity rates of RAFTLIN mRNA was $33.3 \%$. However, among normal control, the positivity rates of RAFTLIN mRNA was $8.3 \%(\mathrm{p}<0.01)$, as shown in Table (3). 
Mariam Sameh Boshra, et al.,

Table 3: Positivity rate of RAFTLIN among the different study groups

\begin{tabular}{|c|c|c|c|c|c|}
\hline & $\begin{array}{c}\text { Malignant } \\
\text { (HCC) } \\
\mathrm{N}(\%)\end{array}$ & $\begin{array}{c}\text { CHC (HCV) } \\
\mathrm{N}(\%)\end{array}$ & $\begin{array}{c}\text { Healthy control } \\
\mathrm{N}(\%)\end{array}$ & $\chi^{2(\mathrm{a})}$ & $\mathrm{P}$ \\
\hline $\begin{array}{l}\text { RAFTLIN mRNA: } \\
\text { Positive (45) } \\
\text { Negative(58) }\end{array}$ & $\begin{array}{c}36(73.5 \%) \\
13(26.5 \%)\end{array}$ & $\begin{array}{c}6(33.3 \%) \\
12(66.7 \%)\end{array}$ & $\begin{array}{c}3(8.3 \%) \\
33(91.7 \%)\end{array}$ & 36.74 & $.000^{* *}$ \\
\hline
\end{tabular}

${ }^{\mathrm{a}} \mathrm{Chi}$ - square test, HCC: Hepatocellular carcinoma, HCV: Hepatitis C virus, CHC: Chronic HCV infection, mRNA: messenger ribonucleic acid, P: P value, ${ }^{* *} \mathrm{p}<0.01$ : Highly Significant, ${ }^{*} \mathrm{p}<0.05$ : Significant, $\mathrm{p}>0.05$ : Non Significant $\mathrm{n}=103$.

As regards the sensitivity, specificity, positive predictive value, negative predictive value and accuracy of serum RAFTLIN $m R N A$ was $(73.5 \%, 83.3 \%, 80 \%, 77.6 \%$ and $78.6 \%)$ respectively, as shown in Table (4).

Table 4: Performance characteristics of the investigated serum RAFTLIN mRNA among different groups of the study.

\begin{tabular}{|c|c|c|c|c|c|c|}
\hline \multirow{2}{*}{ All groups } & $\begin{array}{c}\text { Investigated } \\
\text { biomarker }\end{array}$ & Sensitivity & Specificity & PPV & NPV & Accuracy \\
\cline { 2 - 7 } & RAFTLIN & $73.5 \%$ & $83.3 \%$ & $80 \%$ & $77.6 \%$ & $78.6 \%$ \\
\hline
\end{tabular}
values.

mRNA: messenger ribonucleic acid, PPV: Positive predictive values, NPV: negative predictive

\section{- Expression of the RAFTLIN mRNA in the hepatic tissue of the HCC patients:}

There was high significance difference in the expression of RAFTLIN mRNA between the hepatic cancer tissue and the control tissue as shown in figure (5).

Figure 5: BOXPLOT of Tissue RAFTLIN mRNA as determined by qRT-PCR among the HCC. The data present the median fold changes $n=20$.

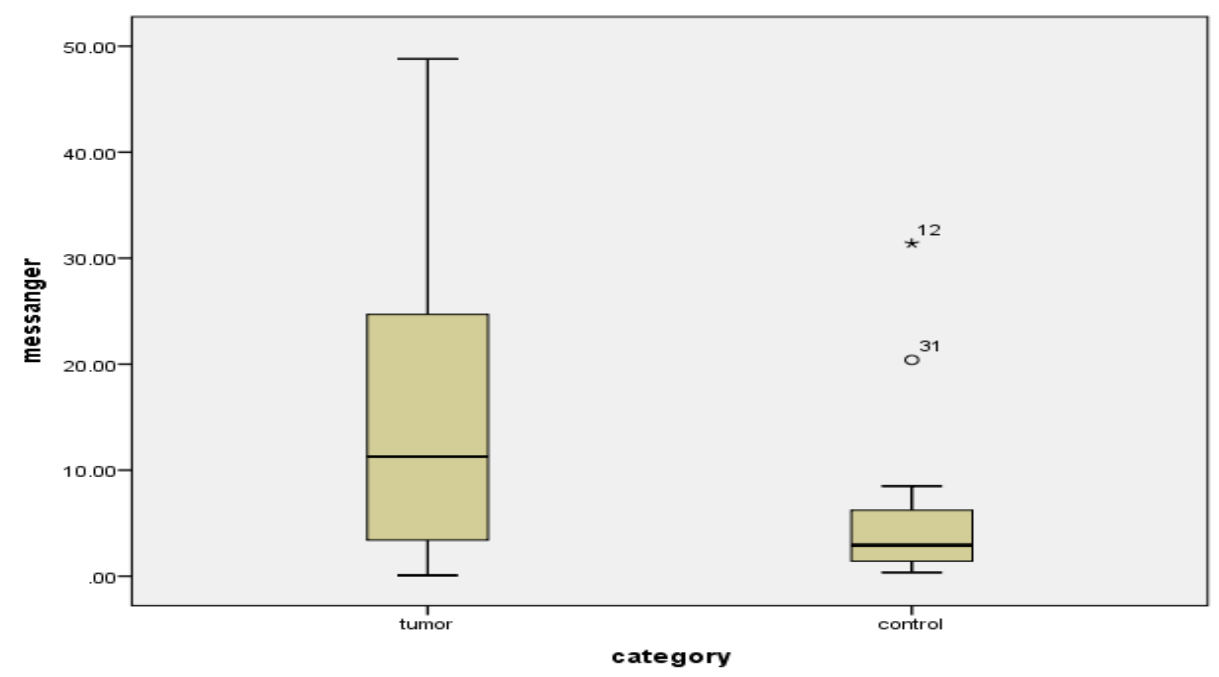

The comparison between RQ values of serum RFTN1 mRNA and the different clinicopathological factors revealed no

significant difference within the malignant group ( $\mathrm{P}>0.05)$, as shown in table (5). 
Table 5: Relation between RFTN1 mRNA RQ, positivity rate and different clinicopathological factors of the malignant group:

\begin{tabular}{|c|c|c|c|c|c|}
\hline Clinicopathological factors & Median & Mean Rank & $\mathrm{N}$ of cases/36 $\geq 1.52(\%)$ & $\mathrm{U}^{(\mathrm{a})}$ & $\mathrm{P}$ \\
\hline $\begin{array}{l}\text { Mean age: } \\
\geq 56.5 \text { years } \\
<56.5 \text { years }\end{array}$ & $\begin{array}{c}3.832 \\
10.5 \\
\end{array}$ & $\begin{array}{c}22 \\
29.74 \\
\end{array}$ & $\begin{array}{l}20(55.6 \%) \\
16(44.4 \%) \\
\end{array}$ & 195 & 0.06 \\
\hline $\begin{array}{l}\text { Sex: } \\
\text { Male } \\
\text { Female }\end{array}$ & $\begin{array}{l}7.42 \\
10.5\end{array}$ & $\begin{array}{l}23.93 \\
26.68 \\
\end{array}$ & $\begin{array}{l}21(58.3 \%) \\
15(41.7 \%)\end{array}$ & 253 & .511 \\
\hline $\begin{array}{l}\text { Smoking: } \\
\text { Smoker } \\
\text { Non-smoker }\end{array}$ & $\begin{array}{l}5.77 \\
10.5 \\
\end{array}$ & $\begin{array}{l}23.23 \\
26.44 \\
\end{array}$ & $\begin{array}{l}16(44.4 \%) \\
20(55.6 \%) \\
\end{array}$ & 258 & 0.433 \\
\hline $\begin{array}{l}\text { HCV-Ab: } \\
\text { Positive } \\
\text { Negative }\end{array}$ & $\begin{array}{c}7.803 \\
11.3\end{array}$ & $\begin{array}{l}24.76 \\
28.67\end{array}$ & $\begin{array}{c}34(94.4 \%) \\
2(5.6 \%)\end{array}$ & 58 & 0.646 \\
\hline $\begin{array}{l}\text { Cirrhosis: } \\
\text { Cirrhotic } \\
\text { Non-cirrhotic }\end{array}$ & $\begin{array}{l}8.007 \\
7.075\end{array}$ & $\begin{array}{l}25.16 \\
23.25\end{array}$ & $\begin{array}{c}33(91.7 \%) \\
3(8.3 \%)\end{array}$ & 83 & .798 \\
\hline $\begin{array}{l}\text { Child-Pugh score: } \\
\text { A4 } \\
\text { A5 } \\
\text { A6 } \\
\text { B5 } \\
\text { B6 } \\
\text { B7 } \\
\text { B8 } \\
\text { C10 }\end{array}$ & $\begin{array}{c}11.3 \\
7.525 \\
5.228 \\
12.20 \\
0.42 \\
2.73 \\
11.90 \\
1.125\end{array}$ & $\begin{array}{c}32.5 \\
25.83 \\
22.25 \\
31.5 \\
1 \\
20.5 \\
33.78 \\
14.63\end{array}$ & $\begin{array}{c}1(2.8 \%) \\
15(41.7 \%) \\
5(13.9 \%) \\
2(5.6 \%) \\
0(0 \%) \\
4(11.1 \%) \\
8(22.2 \%) \\
1(2.8 \%)\end{array}$ & $\chi^{2(b)}=9.97$ & .19 \\
\hline $\begin{array}{l}\text { BCLC stage: } \\
\text { Early } \\
\text { Late }\end{array}$ & $\begin{array}{l}8.66 \\
1.12\end{array}$ & $\begin{array}{l}25.92 \\
14.63\end{array}$ & $\begin{array}{c}35(97.2 \%) \\
1(2.8 \%)\end{array}$ & 48.5 & 0.13 \\
\hline $\begin{array}{l}\text { Average Tumor size } \\
<3 \mathrm{~cm} \\
\geq 3 \mathrm{~cm}\end{array}$ & $\begin{array}{l}8.590 \\
8.007 \\
\end{array}$ & $\begin{array}{l}24.21 \\
25.26 \\
\end{array}$ & $\begin{array}{c}9(25 \%) \\
27(75 \%) \\
\end{array}$ & 212.5 & .825 \\
\hline
\end{tabular}

a: Mann-Whitney test b:Kruskal-Wallis Test. p: NS; Not significant ( $>0.05)$, HCV: Hepatitis C virus, HBVs Ag: Hepatitis B virus surface Antigen, BCLC: Barcelona clinic liver cancer, mRNA: messenger ribonucleic acid.

\section{DISCUSSION:}

Hepatocellular carcinoma (HCC) is the most common primary liver malignancy and is a leading cause of cancer-related death worldwide $^{(9)}$.

This study was conducted on 49 HCC Egyptian patients, 18 chronic hepatitis $\mathrm{C}$ patients and 36 healthy normal volunteers. At first we used the Bioinformatics analysis to retrieve mRNA specific to $\mathrm{HCC}$, then this was followed by validation of the expression of this mRNA in clinical sera and tissue samples.
We found that $\mathrm{HCV}$ and liver cirrhosis were significantly related to $\mathrm{HCC}$, interestingly there was high significant difference in the sera and tissue expression of RAFTLIN mRNA between the HCC group and the group of HCV patients and the healthy control group. RAFTLIN was upregulated in $\mathrm{HCC}$ in comparison to $\mathrm{HCV}$ patients and healthy controls. ROC curve was done to differentiate between HCC and the control groups. It was found that $m R N A$ RAFTLIN can be used to differentiate between HCC patients and people with no HCC. 
RAFTLIN mRNA (Raftlin, Lipid Raft Linker 1); a protein coding gene located on chromosome 3 , expressed in most tissues as brain, liver, immune system and bone marrow $^{(\mathbf{1 0})}$. RAFTLIN has a role in primary open angle glaucoma ${ }^{(11)}$, and found to be down regulated in breast cancer ${ }^{(12)}$.

Alameda et al. found that RAFTLIN was upregulated and has a role in skin cancer development $^{(\mathbf{1 3})}$. On the other hand RAFTLIN was found to be down regulated in microarray study of gene expression in ovarian cancer ${ }^{(14)}$.

The limitation of this study is that it was carried in a single center in Egypt with a relatively small sample size, so, we recommend further large multicentre studies and more in vitro functional studies to elucidate the deep underlying molecular mechanism beyond the role of the chosen gene in HCC.

\section{Conclusion}

In the light of this study, RAFTLIN plays a significant role in HCC pathogenesis that may be a promising diagnostic factor and therapeutic target.

\section{REFERENCES}

1. Singh, A.K., Kumar, R. and Pandey, A.K., 2018. Hepatocellular carcinoma: causes, mechanism of progression and biomarkers. Current chemical genomics and translational medicine, 12, p.9.

2. Akinyemiju T, Abera S, Ahmed M, Alam N, Alemayohu MA, Allen C, Al-Raddadi R, Alvis-Guzman N, Amoako Y, Artaman A, Ayele TA, 2015.The burden of primary liver cancer and underlying etiologies from 1990 to 2015 at the global, regional, and national level: results from the global burden of disease study. JAMA oncology. 2017; 3 (12):1683-91.

3. Elghazaly, H., Gaballah, A. and Eldin, N.B., 2018. P-019 Clinic-pathological pattern of hepatocellular carcinoma (HCC) in Egypt. Annals of Oncology, 29(5): 151018.

4. Siegel R, Naishadham D, Jemal A, 2013. Cancer statistics. CA Cancer J Clin. 2013; 63: 11-30.

5. Chen, H., Zhang, Y., Li, S., Li, N., Chen, Y., Zhang, B., Qu, C., Ding, H., Huang, J. and Dai, M., 2018. Direct comparison of five serum biomarkers in early diagnosis of hepatocellular carcinoma. Cancer management and research, 10, p.1947.

6. Trinchet, J.C., Chaffaut, C., Bourcier, V., Degos, F., Henrion, J. and Fontaine, H., 2011. Groupe d'Etude et de Traitement du Carcinome Hépatocellulaire (GRETCH). Ultrasonographic surveillance of hepatocellular carcinoma in cirrhosis: a randomized trial comparing 3-and 6-month periodicities. Hepatology, 54 (6), pp.19871997.

7. Child CG, Turcotte JG, 1964. Surgery and portal hypertension. Major Probl Clin Surg.; $1: 1-85$.

8. Livak KJ, Schmittgen TD, 2001. Analysis of relative gene expression data using real-time quantitative PCR and the 2(-delta deltaC (T)) method. Methods;25:402-408.

9. Hernaez R, El-Serag HB. Hepatocellular carcinoma surveillance: the road ahead. Hepatology. 2017; 65:771-773.

10. Saeki, K., Miura, Y., Aki, D., Kurosaki, T. and Yoshimura, A., 2003. The B cell-specific major raft protein, Raftlin, is necessary for the integrity of lipid raft and BCR signal transduction. The EMBO Journal, 22 (12), pp.3015-3026.

11. Chen, J.H., Wang, D., Huang, C., Zheng, Y., Chen, H., Pang, C.P. and Zhang, M., 2012. Interactive effects of $\mathrm{ATOH} 7$ and RAFTLIN in association with adult-onset primary open-angle glaucoma. Investigative ophthalmology \& visual science, 53 (2), pp.779-785.

12. Gkretsi, V., Papanikolaou, V., Zacharia, L.C., Athanassiou, E., Wu, C. and Tsezou, A., 2013. Mitogen-inducible Gene-2 (MIG2) and migfilin expression is reduced in samples of human breast 


\section{Evaluation of raftlin mrna in hepatocellular carcinoma}

cancer. Anticancer research, 33 (5), pp. 1977 - 1981.

13. Alameda, J.P., Navarro, M., Ramírez, Á., Page, A., Suárez-Cabrera, C., MorenoMaldonado, R., Paramio, J.M., del Carmen Fariña, M., Del Río, M., FernándezAceñero, M.J. and Bravo, A., 2016. IKKa regulates the stratification and differentiation of the epidermis: Implicat-ions for skin cancer development. Oncotarget, 7 (47), p.76779.

14. Sherman-Baust, C. A., Becker, K. G., Wood III, W. H., Zhang, Y., \& Morin, P. J., 2011. Gene expression and pathway analysis of ovarian cancer cells selected for resistance to cisplatin, paclitaxel, or doxorubicin. Journal of ovarian research, 4 (1), 21.

\section{تقييم الحمض النووى الريبوزى رافتلين فى سرطان الكبد \\ مريم سامح بشرى، محمود شوقى المتينى، ايمن السيد شافعى، مروة متبولى سيد، هبة الله سعيد على سلى}

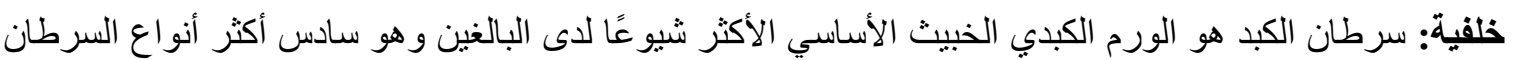

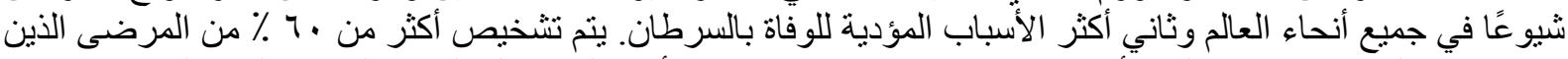

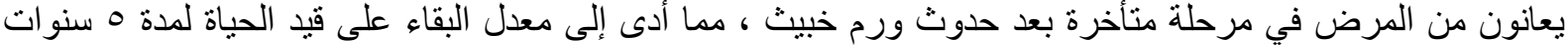

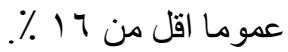

$$
\text { الهذف من البحث: لتوصيف علامة تشخيصية جديدة لسرطان الكبد يمكنها المساعدة في التشخيص المبكر. }
$$

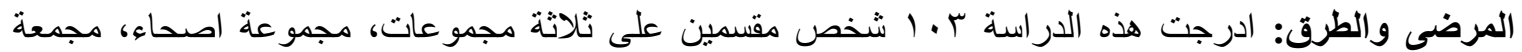

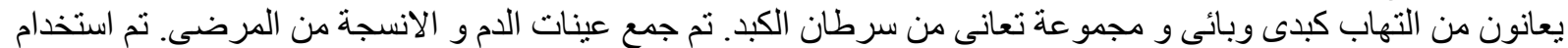

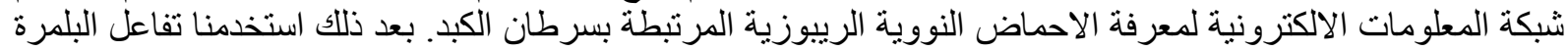
المتسلس لقياس نسبة الحمض النووى الريبوزى المختار رافتلين لقياسه فى عينات الدم و الإنة الانسجة.

النتائج: كان هناك فرق ذو دلالة إحصائية في التعبير عن الحمض النوفين النوى الريبيوزى رافتلين بين المرضى الذين يعانون من سرطان الكبد مقارنة مع المجمو دنتين الأخربين.

الاستتناج: اظهرت النتائج الدور الواعد للحمض النووى الريبوزى رافتلنين كعلامة جديدة للكثف المبكر عن سرطان 